\title{
Green Supply Chain for Better Future Hotel Business
}

\author{
I Ketut Astawa*, I Ketut Budarma, Cokorda Istri Sri Widhari, I Gede Mudana \\ Tourism Department \\ Politeknik Negeri Bali \\ Bali, Indonesia \\ *ketutastawa@pnb.ac.id, ketutbudarma@pnb.ac.id, widhari@pnb.ac.id, gedemudana@pnb.ac.id
}

\begin{abstract}
The purpose of this study is to analyze the integration of green hotels and green supply chain practices for better future hotel business. Data collected through observation, questionnaires, and interviews. This research uses pentagon magic theory of tourism development to analyze aspects of environmentally friendly tourism which is combined with the Triple Bottom Line dimension approach related to economy, environment and social. The respondents are 63 hotel employees determined from Food \& Beverage department, purchasing, receiving and inventory. Respondents were determined by the characteristics of their knowledge and understanding of the supply chain management activities that are interrelated with departments in hotels. The findings show that respondents have a positive attitude towards green hotels and green supply. Hotel management and related business operators surveyed believe that standards must be set for green hotels and green supply. If conventional hotels and environmentally friendly hotels serve the same function, green hotels will be the preferred choice. Green hospitality business practices are able to improve environmental performance, business impact can enhance brand image as a business that cares the environment and as a strategic marketing tool to enhance its unique competitiveness. The results indicate that there is a tendency for consumers' tastes to be environmentally friendly products in Bali. Future research is suggested to build a model that can be adopted by green hotels to include premiums in the price of their facilities. It also aims to create awareness among hotel facility operators about the various benefits associated with being green. The potential benefit of this research is to enhance the brand and company image of the hotel in addition to contributing to a sustainable environment.
\end{abstract}

Keywords-green hotel, green supply chain, hospitality business

\section{INTRODUCTION}

Nowadays, tourists are getting smarter and more selective in choosing hotels that really consistently implement environmentally friendly practices by utilizing energy-efficient resources based on local products or who are members of the green industry. Sustainable tourism has become a vision for most of those involved in the tourism business, including in Bali [1]. Rahmafitria in her research revealed that accommodation with environmentally friendly concepts and management is one of the parameters driving tourists to choose accommodation facilities [2]. Kuminoff conducted a study on the willingness of travelers to pay a premium for a hotel that promotes greenness. The research found that 'greenness' was increasingly becoming a search criterion among travelers and also that hotels in the USA charge a premium for their greenness [3]. Other research results state that destination that ensures greening as a part of their organizational central goal can have a competitive advantage in the tourism industry [4]. Also, in the US, the green momentum is growing globally and that becoming green could be an opportunity for hotels to create a competitive advantage, even though direct links between the environment and profitability are unsubstantiated [5].

In response to the consumer's change of preference towards green products and services, the hotel industry is adopting sustainable practices and advertised towards potential customers [6]. An environmentally friendly hotel can be categorized as the one that offers sustainable services and focuses on minimizing its negative impacts on the environment through reusing, reducing, and recycling. It is used by an ecofriendly use of water and energy [7]. Going green is important to attract the new segment of conscious consumers and to stay competitively relevant to the targeted market, but is also financially beneficial for the related tourism industry.

The concept of green products is related to sustainable manufacturing and supply chain management, which involves environmentally friendly, planet friendly, and people friendly standards, technologies and practices. The concept of green is extended to almost every process step of procuring raw materials, producing, storing, packaging, shipping, and distribution [8]. An environmentally friendly product seems a new growth paradigm for a higher quality of life through the creation of wealth and competitiveness. In line with this paradigm, the green consumers choose green products by virtue of their consciousness about environmental benefits, economic benefits, green reliability, and green appearance of the product [9].

Green hotel and green supply chain are better future hospitality business characterized by their small-scale activity, aiming at preserving the environment, and respecting the host community cultures. Green hotel certainly opens opportunities and challenges to the supply of processed raw materials from 
suppliers so that the integration of green provides an opportunity to capture the eco-friendly tourist market segment.

Related to the problem studied, namely green supply chain for better future hotel business, this study uses tourism development's theory to analyze the aspect of eco-friendly tourism which in this research focusing on green hotel and green supply chain as in Figure 1 [10].

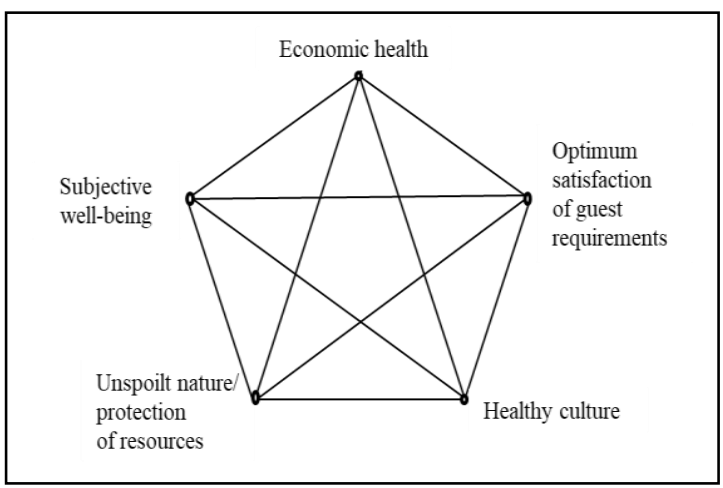

Fig. 1. The thorny path to sustainable tourism development.

This theory describes the main components of sustainable tourism consisting of unspoilt nature, healthy culture, high levels of subjective well-being, optimal satisfaction of guest requirements and economic health. Based on this theory, the ideal life is a continuous harmony that is interrelated between these main components. Economic health is in the top position as a driving force for the harmony of the welfare of the host community with tourist satisfaction. The involvement of local communities with tourist satisfaction is on an equal footing in order to realize a healthy economy, unspoilt nature, and healthy culture.

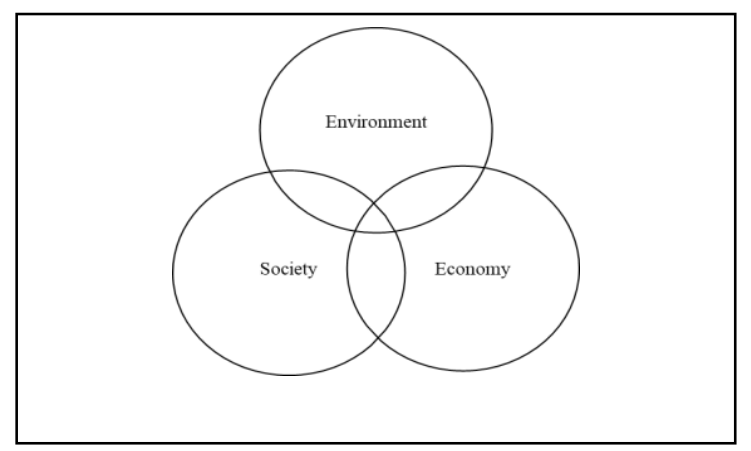

Fig. 2. The triple bottom line.

Green supply chain for better future hotel business is combined with the approach of the Triple Bottom Line (TBL) dimension from John Elkington [11] relating to the economy, environment, and social. Green businesses are relevant trends in relation to the TBL dimensions which society depends on the economy and the economy depends on the global ecosystem; whose health represents the ultimate bottom line (Figure 2). The purpose of this study is to analyze the integration of green hotels and green supply chain practices for better future hotel business. Research locations in 5-star hotels in Bali with a population of 57 hotels receiving THK Tourism Award. The potential benefits of this study will be to improve the brand and corporate image of the hotel alongside contributing to a sustainable environment.

\section{RESEARCH METHODOLOGY}

This is a qualitative research. The method used in this research is descriptive qualitative method. The type of descriptive qualitative research used is case study approach. This research was conducted at six 5-star hotel in Bali: Melia Bali; St. Regis Bali; Intercontinental Hotels; Conrad Bali; Mandapa Bali; and The Royal Pita Maha Resort. The respondents are 63 hotel employees determined from Food \& Beverage department, purchasing, receiving and inventory. Respondents were determined by the characteristics of their knowledge and understanding of the supply chain management activities that are interrelated with departments in hotels. The procurement needs of goods at the hotel are related to the Food $\&$ Beverage department, the purchasing department compiles the needs of each department and determines the price. The receiving section deals with receiving and checking the suitability, quality and quality of the goods received, while the inventory section will arrange the storage and release of goods as needed. Primary data obtained through observation, questionnaires, and interviews. Qualitative data analysis techniques were carried out by researchers starting in the field and after the data was collected. The data processing starts from editing the data from observations, interviews, documentation studies, then classifying, reducing these data so that they are arranged in groups [12].

\section{RESULTS AND DISCUSSION}

\section{A. Green Hospitality Business Practices at The Hotels' Policy Level}

Indicators in the implementation of green at the policy level are a reference umbrella for achieving joint results including 10 indicators: 1) environmental \& social sustainability. This indicator relates to regulating the environment, taking into account positive or negative effects that may arise, not only concerning waste and air pollution, but also with regard to society with its culture which in essence does not harm the environment. The implementation is revealed in the Standard Operational Procedure (SOP) which regulates one of them regarding the percentage of the participation of human resources (HR) from the local population, commitment to use local products, sustainability in environmental preservation; 2) social \& environment issues; 3) commits to continually improve the environment, committed to protecting the environment of all stakeholders including government and society; 4) annual benchmarking, by conducting internal audits on an ongoing and consistent basis. It aims to maintain continuous quality standards; 5) environmental management system (EMS), relating to the management of waste, energy, and water management; 6) Tri Hita Karana, adopting the value of local wisdom to preserve the environment, EarthCheck standard, one of the standards that must be included in the policy because it is a hotel chain, naturally follows international standards; 7) other relevant legislations \& 
regulations, relevant regulations issued by the local government of Bali in particular and Indonesia in general; 8) best practice, do not rule out the possibility of looking for best practice carried out by other companies (hotels), which later support the established program; 9) special consideration for local employing and empowering, how to consider the percentage of local human resources (Bali), outside Bali and expatriate; and 10) environmental \& social sustainability champion, by forming a Green Champion.

Related to green certificates, the sample hotel adopts environmentally friendly business practices from local wisdom values, namely Tri Hita Karana (THK). In addition to adopting the values of local wisdom, there are also global values that are used as a reference for the implementation of environmentally friendly business practices such as EarthCheck, Gold Travel Life, Green Hotels, Proper, Ecolabel, ISO14002, and HACCP Certification/Agriculture and Food. Adopting local values and global values is one of the green activities in supporting environmentally friendly and saving energy with Earth Hour. The certificate is used as a platform to position the hotel as having practiced green hospitality business practices. Its application is in the proportion of $40 \%$ of buildings and $60 \%$ of supporting land used to provide land with park functions. The hotel also took the initiative to collect and maintain rare plants.

Commitments of business owners, company management and operational staff are stated in the policy statement and implemented fully at the operational level of the business. Green commitment is manifested in the establishing an environmental committee (green team) and supported by green champion from senior management for green team's success. Commitments relating to aspects of society are reflected through harmonious relations between humans and other human beings, can be seen from the commitment of the hotel to recruit as much as possible local workers.

Integrated green champions committee can educate, empower and continue campaigns to get involved all staff to do energy and water saving. At the policy level, learning and development as an umbrella to build internalization between departments. Furthermore, the role is to integrate green in each department according to the company's vision and mission. For example, St. Regis set its vision as: "True hospitality will bring to a place that was never imagined before", and its mission is Educate and help develop an understanding of sustainability. Vision and mission are then revealed in programs that support the maintenance of green behavior. The royal Pita Maha Resort positions itself as one of the five-star private villa resort hotels which are the first choice in Bali precisely in the Ubud area by prioritizing Balinese culture and characteristics. The vision was revealed in the mission by strengthening management of resort hotels for the satisfaction of customers, in line with optimally developing and preserving the culture and nature contained in the Ubud area of Bali for tourist destinations.

\section{B. The Adoption of a Green Innovation Strategy}

Respondents' perceptions and responses to the adoption of an environmentally friendly innovation strategy as in Table I.
TABLE I. RESPONSES ON IMPLEMENTING GREEN INNOVATION STRATEGIES

\begin{tabular}{|l|l|l|l|l|l|}
\hline \multirow{2}{*}{ Category } & \multicolumn{5}{|c|}{ The response } \\
\cline { 2 - 6 } & $\begin{array}{c}\text { Stron } \\
\text { gly } \\
\text { dis- } \\
\text { agree } \\
(\%)\end{array}$ & $\begin{array}{c}\text { Dis- } \\
\text { agree }\end{array}$ & $\begin{array}{c}\text { Neut } \\
\text { ral }\end{array}$ & Agree & $\begin{array}{c}\text { Strong- } \\
\text { ly } \\
\text { agree } \\
(\%)\end{array}$ \\
\hline $\begin{array}{l}\text { Management is } \\
\text { committed to implement } \\
\text { green }\end{array}$ & 0 & 0 & 3.2 & 52.4 & 44.4 \\
\hline $\begin{array}{l}\text { Innovate by negotiating } \\
\text { competitive contracts }\end{array}$ & 0 & 0 & 6.3 & 55.6 & 38.1 \\
\hline $\begin{array}{l}\text { Build a team in an effort } \\
\text { to support the } \\
\text { transformation of the } \\
\text { green platform } \\
\text { organization }\end{array}$ & 0 & 0 & 3.2 & 58.7 & 38.1 \\
\hline $\begin{array}{l}\text { Select senior leaders } \\
\text { who are committed to } \\
\text { teamwork and supported } \\
\text { with adequate } \\
\text { communication facilities. }\end{array}$ & 0 & 0 & 6.3 & 61.9 & 31.7 \\
\hline
\end{tabular}

Table I shows the response to the adoption of an environmentally friendly innovation strategy, $96.8 \%$ states that management is committed to implement green, innovating by negotiating competitive contracts, building teams in an effort to support the transformation of the green platform organization. The activity is a management commitment in selecting senior leaders who value teamwork and are supported by adequate communication facilities.

Management also has support in promoting team activities with members who have green commitments and experts in their fields. However, $79 \%$ said they had implemented an environmentally friendly innovation strategy by holding regular meetings between hotel owners and management and environmentally friendly suppliers. This is done as an effort to maintain the sustainability of logistical activities and grow suppliers' commitment to understand hotel needs. The results of this study support the results of research which states that businesses can improve environmental performance, business impacts can enhance brand image as a business that cares about the environment and as a strategic marketing tool to enhance its unique competitiveness [13].

\section{Green Product and Natural Environment}

Green products are products with low environmental impacts. Green products present as one of the solutions for environment sustainability issue. The increase of consumer awareness about health and environmental issues has improved the consumption on green products and organic food these last few years [14]. The research of Yadav and Pathak [15] showed that the intention to use green products is not limited to only adult consumers, but also to the young ones. Consumers are demanded to be willing to pay premium price in order to consume green products. In response to the consumer's change of preference towards green products and services, the hotel industry is adopting sustainable practices and advertising towards potential customers [16].

In line with the research results that have been previously mentioned, the results of this study found that the hotels used 
as research samples explores product innovation by utilizing local products and local expertise as an environmentally friendly business opportunity. For example, loloh (Balinese traditional drink) is served for a welcome drink, using straw from paper or bamboo. At the time of check-in guests are also given tridatu yarn ( 3 thread colors: white, red and black) as a welcome blessing. Other innovative products are presented by using arak (Balinese traditional wine with a relatively high alcohol content) to introduce archipelago beverages other than herbal medicine. Other products that are environmentally friendly such as carpets made from water hyacinth and bed covers from tenun ikat (woven ikat fabrics). Initiatives to make tourism more inclusive can be seen as attempts to improve the quality of human interaction, and to ensure that tourism delivers benefits to those who have in the past been excluded from, or marginalized by, its production and consumption [17]. Respondents' responses to the evaluation of green implementation at the operational level as in Table II.

TABLE II. RESPONSES ON EVALUATIONS OF GREEN IMPLEMENTATION

\begin{tabular}{|c|c|c|c|c|c|}
\hline \multirow[t]{2}{*}{ Category } & \multicolumn{5}{|c|}{ The response (evaluation) } \\
\hline & $\begin{array}{l}\text { Very } \\
\text { poor } \\
(\%)\end{array}$ & $\begin{array}{r}\text { Poor } \\
\text { (\%) }\end{array}$ & $\begin{array}{l}\text { Fair } \\
\text { (\%) }\end{array}$ & $\begin{array}{c}\text { Good } \\
\text { (\%) }\end{array}$ & $\begin{array}{c}\text { Very } \\
\text { Good } \\
\text { (\%) }\end{array}$ \\
\hline $\begin{array}{lll}\begin{array}{l}\text { Partnership } \\
\text { organizations }\end{array} & \text { with } & \text { green } \\
\end{array}$ & 0 & 0.0 & 12.7 & 54.0 & 33.3 \\
\hline $\begin{array}{l}\text { Green knowledge transfer and } \\
\text { communication }\end{array}$ & 0 & 1.6 & 9.5 & 61.9 & 27.0 \\
\hline Product recycling rate & 0 & 1.6 & 14.3 & 52.4 & 31.7 \\
\hline Product reuse rate & 0 & 4.8 & 15.9 & 47.6 & 31.7 \\
\hline $\begin{array}{ll}\begin{array}{l}\text { Environmental } \\
\text { certificates }\end{array} & \text { related } \\
\end{array}$ & 0 & 1.6 & 17.5 & 52.4 & 28.6 \\
\hline $\begin{array}{l}\text { Choosing } \quad \text { suppliers } \\
\text { environmental criteria }\end{array}$ & 0 & 0 & 12.7 & 54.0 & 33.3 \\
\hline
\end{tabular}

Table II shows the response on the evaluation of green implementation, more than $87 \%$ stated that the company have implemented partnerships with green organizations. The implementation of green is supported because the respondents feel the benefits of green knowledge transfer and communication. Commitment in reusing the use value of goods has been done by product recycling and product reuse.

The integration of green supply chains and green hotels at the operational level pays more attention to accuracy because of responsibilities related to environmental certificates. This accuracy can be seen from the response that more than $87 \%$ stated that the company has implemented supplier selection with environmental criteria. Procurement procedures start from the stage of preparing the purchase request until the receipt of goods following the green corridor. That is, the receipt of goods needed in operational activities is checked for quality and quantity before use.

Table I and Table II can be synthesized that a profit will be achieved if there are people who have competence in their field of work. Human resources who have a vision and mission committed to achieve the goals that have been determined to maximize profits. However, these people may not exist if there is no environment or place to live. So, it is very wise as a human to change the mindset in exploiting the environment as a target in meeting business needs. Characteristics of green products related to environmentally friendly commitments identified as such: 1) contributing to the conservation of ecosystems, while respecting the participation of local communities, 2) respecting the carrying capacity of the local natural environment, not giving no pressure and negative impacts, 3 ) respecting and being responsive on the aspirations of the local community, 4) understanding and giving appreciation to other cultures, 5) providing long-term benefits for the country, region and local community. This finding is in line with the research results from Donohoe [18] and those related to the carrying capacity of tourism areas in line with the results of research from Astawa [19].

\section{Integration of Green Supply Chains and Green Hotels}

The integration of environmentally friendly business practices promotes mutually beneficial solutions and minimizes the chance of environmental damage. Towards the development of sustainable tourism also needs to be supported by a beautiful environment that is sustainable. Business activities should be based on awareness to pay attention to the fulfillment of the welfare of the community (people) and contribute actively in protecting the environment (planet). The benefit from the integration of green supply chain and green hotel in terms of environmentally friendly business practices presented in Table III.

TABLE III. RESPONSES ON ENVIRONMENTALLY FRIENDLY BUSINESS PRACTICES

\begin{tabular}{|l|l|l|l|l|l|}
\hline \multicolumn{2}{|c|}{ Category } & \multicolumn{5}{|c|}{ The response } \\
\cline { 2 - 6 } & $\begin{array}{c}\text { Strong- } \\
\text { ly dis } \\
\text { agree } \\
(\%)\end{array}$ & $\begin{array}{c}\text { Dis- } \\
\text { agree }\end{array}$ & $\begin{array}{c}\text { Neut } \\
\text { ral }\end{array}$ & $\begin{array}{c}\text { Agree } \\
(\%)\end{array}$ & $\begin{array}{c}\text { Strong- } \\
\text { ly agree } \\
(\%)\end{array}$ \\
\hline $\begin{array}{l}\text { Low operational } \\
\text { costs }\end{array}$ & 1.6 & 3.2 & 22.2 & 39.7 & 33.3 \\
\hline $\begin{array}{l}\text { Relationships last } \\
\text { for a long time (long } \\
\text { contract period) }\end{array}$ & 0 & 7.9 & 12.7 & 50.8 & 28.6 \\
\hline $\begin{array}{l}\text { The company is } \\
\text { sensitive to changes } \\
\text { in consumer demand }\end{array}$ & 0 & 5 & 19.0 & 54.0 & 22.2 \\
\hline $\begin{array}{l}\text { Supplier } \\
\text { understands hotel } \\
\text { needs }\end{array}$ & 0 & 0 & 6.3 & 39.7 & 54.0 \\
\hline $\begin{array}{l}\text { The supplier is } \\
\text { committed to the } \\
\text { hotel }\end{array}$ & 0 & 0 & 6.3 & 42.9 & 50.8 \\
\hline
\end{tabular}

Table III shows the response on environmentally friendly business practices, more than $70 \%$ stated that the company perceived benefits at low operational costs. Hotel samples can save from energy \& water as much as Rp. 14,429,743 per month and less chemicals are used which is reducing $25 \mathrm{~kg}$ of chlorine and 30 liters of $\mathrm{Hcl}$ [20]. More than $90 \%$ of respondents said that suppliers understand hotel needs so as to generate trust that results in commitment to long-term business relationships. The results of this study confirm the findings of Brebbia [21] who claim that financial savings are one of the most significant factors that influence the implementation on environmental initiatives in a hotel. 


\section{CONCLUSION}

Commitments of business owners, company management and operational staff are stated in the hotels' policy statement and implemented fully at the operational level of the business. Green commitment is manifested in the establishing an environmental committee (green team) and supported by green champion from senior management for green team's success. The management is committed to implement green, innovating by negotiating competitive contracts, building teams in an effort to support the transformation of the green platform organization. The activity is a management commitment in selecting senior leaders who value teamwork and are supported by adequate communication facilities. This is done as an effort to maintain the sustainability of logistical activities and grow suppliers' commitment to understand hotel needs. Green hospitality business practices are able to improve environmental performance, business impact can enhance brand image as a business that cares the environment and as a strategic marketing tool to enhance its unique competitiveness.

The company has implemented partnerships with green organizations. The implementation of green business practice is supported because of the benefits of green knowledge transfer and in such an implementation communication. Commitment in reusing the use value of goods has been done by product recycling and product reuse. The company perceived benefits at low operational costs. The energy \& water saving initiatives save Rp 14,429,743 per month as well as less chemical used reduces $25 \mathrm{~kg}$ of chlorine and 30 liters of $\mathrm{Hcl}$. More than $90 \%$ of the respondents said that suppliers understand hotel needs so as to generate trust that results in commitment to long-term business relationships.

Research relating to carrying capacity and the use of local products to support green-based tourism activities needs to be developed to stimulate the economy of local communities as supporters or hosts of tourism activities themselves. Green practice research related to the phenomenon of overtourism also needs to get attention for researchers who have an interest in the green field.

\section{ACKNOWLEDGMENT}

This paper is part of the academic research funded by the List of Budget Implementation List (DIPA) Directorate of Research and Community Service, Ministry of Research and Technology/National and Innovation Agency Number SP DIPA-042.06.1.401516 / 2020, dated November 12, 2019. The authors are grateful to the Director of PNB, the students that helped collect research data, and the business management of the hospitality industry in Bali.

\section{REFERENCES}

[1] A. A. G. R. Dalem, Achievements and challenges of implementation of "Tri Hita Karana" for creating sustainable tourism in Bali-Indonesia: A case study in hotel sectors. (Unpublished manuscript). 5-12. 2010.

[2] F. Rahmafitria, "Eco-Resort dan Green Hotel di Indonesia". Jurnal Manajemen Resort \& Leisure, 11(2), pp. 1-22. 2014. https://doi.org/10.1108/09596119910272739
[3] N. V. Kuminoff, C. Zhang, and J. Rudi, "Are travelers willing to pay a premium to stay at a "green" hotel? Evidence from an internal metaanalysis of hedonic price premia". Agricultural and Resource Economics $\begin{array}{llll}\text { Review, } & 39(3), & \text { pp } & 468-484 .\end{array}$ https://doi.org/10.1017/S1068280500007450

[4] J. S. Lee, D. Breiter, and Y. Choi, "Quality of a Green Destination as Perceived by Convention Attendees: The Relationship between Greening and Competitiveness". Graduate Student Research Conference in Hospitality and Tourism, (1995). 2011. Retrieved from http://scholarworks.umass.edu/gradconf_hospitality/2011/Presentation/4

[5] N. A. Barber, "Profiling the Potential "Green" Hotel Guest: Who Are They and What Do They Want?" Journal of Hospitality and Tourism Research, 38(3), pp. 361-387. 2014 https://doi.org/10.1177/1096348012451462

[6] P. Martínez, G. D. Leaniz, Á. H. Crespo, and R. Gómez, "Customer responses to environmentally certified hotels : the moderating effect of environmental consciousness on the formation of behavioral intentions". 9582(July), $\quad$ pp. $0-18.2017$. https://doi.org/10.1080/09669582.2017.1349775

[7] G. J. Dalton, D. A. Lockington, and T. E. Baldock, "A survey of touris attitudes to renewable energy supply in Australian hotel accommodation". Renewable Energy, 33(10), pp. 2174-2185. 2008. https://doi.org/10.1016/j.renene.2007.12.016

[8] R. Palevich, "The Lean Sustainable Supply Chain: How to Create a Green Infrastructure with Lean Technologies". 2012.

[9] P. Maniatis, "Investigating factors influencing consumer decisionmaking while choosing green products". Journal of Cleaner Production, 1(14). 2015

[10] H. Müller, "The thorny path to sustainable tourism development The Thorny Path to Sustainable Tourism Development". (February 2015), pp. 37-41. 2009. https://doi.org/10.1080/09669589409510690.

[11] J. Elkington, Canibals With Forks. the triple bottom line of 21st century business. 2001

[12] M. B. Miles and A. M. Huberman, Qualitative data analysis: An expanded sourcebook (2n ed). London: Sage publications. 1994.

[13] A. Rohdayatin, P. Sugito, and K. Handayani, "Green Supply Chain: Studi Keterkaitannya dengan Kinerja Lingkungan dan Kinerja Finansial”. Jurnal Manajemen Dan Kewirausahaan, 6(2), 103-114. 2018. https://doi.org/10.26905/jmdk.v6i2.2513.

[14] M. Ertz, F. Karakas, and E. Sarigöllü, "Exploring pro-environmenta behaviors of consumers: An analysis of contextual factors, attitude, and behaviors". Journal of Business Research, 69(10), pp. 3971-3980. 2016.

[15] R. Yadav and G. S. Pathak, "Determinants of consumers' greenpurchase behavior in a developing nation: Applying and extending the theory of planned behavior". Ecological Economics, 134, 114-122. 2017

[16] P. Martinez Garcia de Leaniz, A. Herrero Crespo, and R. Gómez López, "Customer responses to environmentally certified hotels: The moderating effect of environmental consciousness on the formation of behavioral intentions". Journal of Sustainable Tourism, 26(7), pp. 1160 1177. 2018

[17] R. Scheyvens and R. Biddulph, "Inclusive tourism development". Tourism Geographies, 20(4), pp. 589-609. 2018 https://doi.org/10.1080/14616688.2017.1381985.

[18] H. M. Donohoe and R. D. Needham, "Ecotourism: The evolving contemporary definition". Journal of Ecotourism, 5(3), 192-210. 2006.

[19] I. K. Astawa and A. A. Putri Suardani, "Spatial Carrying Capacity in Kuta Tourism Area for Revisiting Tourists". PEOPLE: International Journal of Social Sciences, 3(2), pp. 1804-1821. 2017. https://doi.org/10.20319/pijss.2017.32.18041821

[20] N. I. W. Wirantaja, Green Sustainability Program, St Regis Bali: The material was delivered at the Focus Group Discussion. 2019.

[21] C. A. Brebbia and F. D. Pineda, Sustainable Tourism. (Boston: WIT Press). 2004. 